\title{
Application of DPSIR Framework to Explore Effectiveness of Solid Waste Management in the Maldives
}

\author{
Fathmath Shadiya \& Ali Fawaz Shareef \\ Maldives National University, Male', Republic of Maldives \\ fathimath.shadiya@mnu.edu.mv
}

\begin{abstract}
Waste management in preindustrial times was simple because most of the waste consists of organic materials which decompose naturally. However with the change in consumption patterns of the Maldivians, non- biodegradable synthetic materials such as plastic have become one of the leading causes of marine and coastal pollution in the Maldives. In an attempt to identify a low cost efficient approach of Solid Waste Management system across the country, the Maldivian government has introduced a community based solid waste management system at island level. Hence, the main focus of this study is to explore factors that influence effectiveness of Community Based Solid Waste management systems implemented at island level, using Driver, Pressure, State, Impact, Response (DPSIR) framework. Community participation, community satisfaction level and community willingness to pay for the new system was evaluated in the study. Analysis of data showed, even though most people in the community were satisfied with the new system, there was no association between community satisfaction level and their willingness to pay for the sustenance of the new system. In addition, even though community was aware about plastic pollution, there was no association between community perception about plastic pollution and their willingness to adopt green consumer behaviors. The results also showed that even though majority of community members were satisfied with the current model of waste management system, the current system does not address the driving factors that contributes to solid waste generation at island level.
\end{abstract}

Keywords: Sustainability, Community Based Solid Waste Management System, DPSIR framework.

\section{Introduction}

The tourism industry contributes $37 \%$ of the country's economy while fisheries industry is the second largest contributor of economic development in the Maldives. (Ministry of Tourism, 2015). Tourism and fisheries industry heavily rely on marine and coastal ecosystems for livelihood activities; as a result, coastal habitats are key ecologies that are linked to livelihood of a large percentage of the Maldivians. Any threat to these key ecologies will have a damaging impact on Maldivian economy. However, over the years, due to population growth and change in consumer lifestyle of the Maldivians, marine and coastal pollution has become a pressing concern for the tourism and fisheries industry. 
Fathmath Shadiya \& Ali Fawaz Shareef; Title: Application of DPSIR Framework to Explore Effectiveness of Solid Waste Management in the Maldives.. Journal of Biomedical Engineering and Medical Imaging, Volume 7, No 1, February (2020), pp 10-17

According to (Ministry of Tourism, 2015) statistics, 860 metric tons of solid wastes are generated in the Maldives every day, and in the absence of a proper solid waste management system, most of the solid waste generated in the Maldives, end up in beaches, lagoons and mangroves causing harm to the biodiversity of these unique ecologies, tourism and fisheries industry depends on. However, being a small island nation, Maldives faces enormous challenges in solid waste management due to land scarcity, geographic isolation, small economy of scale and lack of financial and human resources. (Fry, 2005). All of these factors make implementation of a low cost solid waste management system very difficult even though many islands have infrastructure needed to manage solid waste.

What is lacking throughout the Maldives is a good governing system to manage solid waste across the country. To solve this issue, in 20211, the government of Maldives in collaboration with World Bank has introduced Community Based Solid Waste Management System (CBSWMS) to five islands of the Maldives. (Shumais, 2014). Community based solid waste management system begins at household level where the households are expected to segregate their solid waste. The segregated solid wastes are then collected by the island council by charging a small fee from the households. Once the waste is collected, and taken to the solid waste management center, the waste is treated or recycled by the staff employed by the island council. Since the initial collaboration for the system takes place from household level, success of such a system heavily depends on the perception and attitude of the households towards the solid waste management system in place. Therefore the focus of this research is to explore household attitude, perception, and their willingness to pay for the sustenance of CBSWMS in light of DPSIR framework.

DPSIR framework is a framework developed originally from Pressure- State-Response (PSR) framework by Organization of Economic Cooperation and Development during 1994. (OECD, 1994). However due to limitations of PSR framework, the UN commission on sustainable development, developed a new framework called Driving -Force- State -Response, (DSR) framework during 1997. Neither PSR nor DSR framework addresses the underlying facts behind responses in the changes of the environment, therefore in 1999, a new framework called DPSIR framework was developed by European Environmental Agency (EEA). (Carr et al., 2007). One of the advantages of DPSIR framework is, the framework can be used as a tool to study community perception and attitudes regarding development projects, because the framework has the ability to give clarity and valuable information about relationship between root causes of problems and their consequences that arise from developmental projects on the environment and the community. (Skondras \& Karavitis, 2015). Figure 3, shows elements of DPSIR framework.

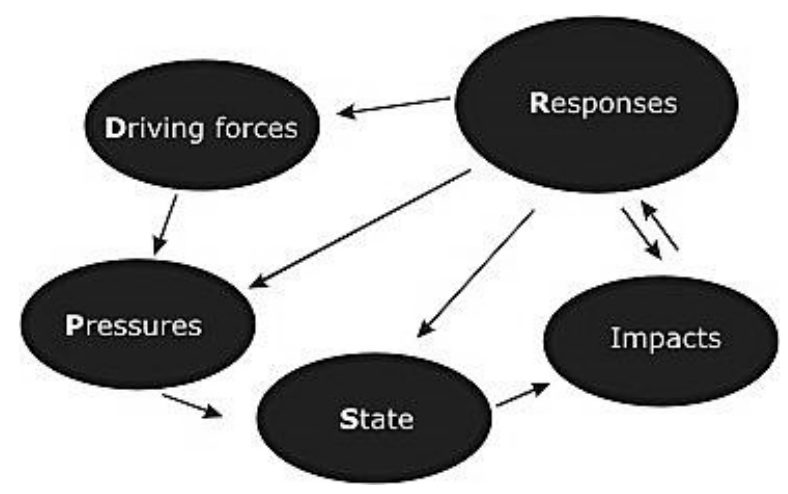

Figure 1: DPSIR framework developed by European Environmental Agency in 1999. 
DPSIR framework shown in figure 1 consists of Drivers, Pressures, State, Impacts and Responses as elements of the framework. The driving force is the special "needs" that arise from social and economic development in the society. Because of these societal needs, specific human activities lead to pressure on the environment in the form of environmental damage and habitat destruction of natural ecosystems. This degradation of the natural ecosystems is referred to as "state" in the framework. The negative consequences on the biotic and abiotic components of the natural ecosystems are referred to as "impacts" in the framework and the community reaction to such consequences is captured as "responses". (Maxim, Spangenberg, \& O'Connor, 2009).

Even though DPSIR framework is an easy tool to assess the impacts of developmental projects on the community, the framework comes with some limitations such as, the framework's inability to suggest non liner relationships, inability to take into account natural drivers of environmental changes like climate change, volcanic eruptions, natural disasters and failure to explain new developments or trending progresses except by recapitulating the study of the identical indicators at consistent intervals. (Skondras \& Karavitis, 2015). Despite these limitations, DPSIR framework still manages to capture key relations between issues in the society and the environment in a simplistic framework that is easy to understand by everyone, and because of this reason, DPSIR framework was chosen for this study. Figure 2 shows the conceptual framework developed based on DPSIR framework for this study.

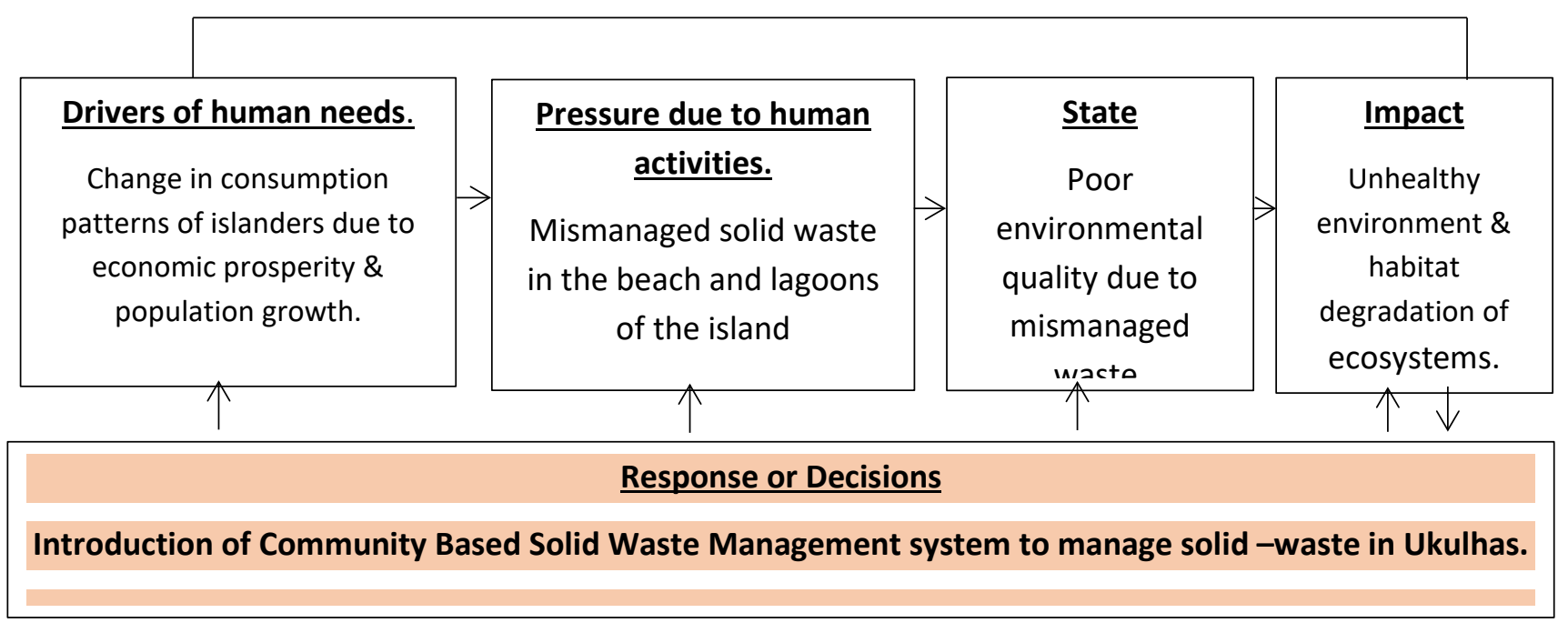

Figure2: Conceptual framework developed from DPSIR framework for this study 


\section{Research Methods}

The field work for the study was conducted in the island of Ukulhas.

\subsection{Study site}

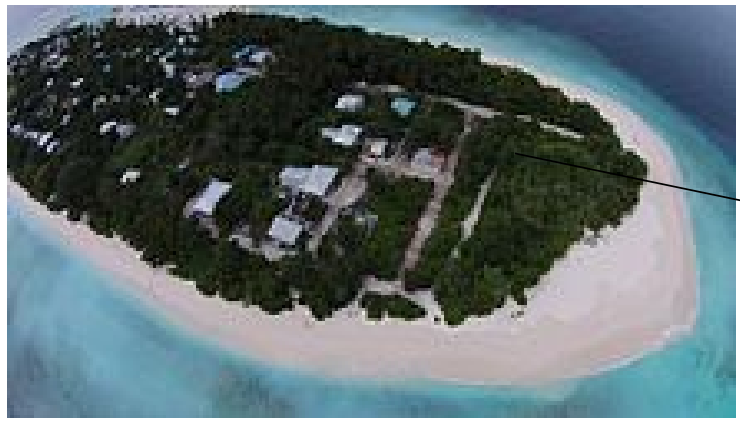

Haa Alliu Atoll

Shavlyani Atoll

Raa Atoll Noonu Atoll

Baa Atoll Lhavlyani Atoll

North Male Atoll

North Ari Atoll>

South Ari Atoll

Faafu Atoll

Dhaalu Atoll

Thas Atoll

Laamu Atoll

Gaafu Allfu Atoll

Gaafu Dhaal Atoll

Gnavlyani Atoll

Seenu Atoll

Figure3: Ariel view of Ukulus. Source: Google Image.

Ukulhas is an island located 44 miles away from the capital city Male' with a population of 1005 people (National Bureau of Statistics, 2014). Ukulhas is considered as the first island to implement a Community Based Solid Waste Management System at island level to systematically manage solid waste. (UNDP, 2012). Solid waste generated at household level is separated into recyclable items, kitchen waste and leaf litter. Once the waste is transported to the waste management center, recyclable items such as Aluminum cans, iron cans, copper wire and old furniture are sold every six months. Organic wastes collected from households are decomposed to make compost which is sold to farmers and resorts. To capture people's attitude and perception towards the CBSWS, a cross sectional survey was carried out by applying random sampling method to the community of Ukulhas. The total population registered for waste management service was 137 household. The sample size for sampling was 102 household, with 5\% margin error, at 95\% confidence level. From each household, the person in charge of handling waste was questioned during the survey. The survey instrument was a close ended questionnaire.

\section{Results}

Table 1: Respondent's willingness to pay a fee for the waste collection service offered by the island council.

\begin{tabular}{|c|c|c|}
\hline Fee rate & Frequency & Percent \\
\hline 100 & 32 & 31.4 \\
\hline 150 & 32 & 31.4 \\
\hline 200 & 19 & 18.6 \\
\hline 250 & 7 & 6.9 \\
\hline 300 & 8 & 7.8 \\
\hline
\end{tabular}




\begin{tabular}{|c|c|c|}
\hline 350 & 4 & 3.9 \\
\hline Total & 102 & 100.0 \\
\hline
\end{tabular}

Table 1 show that $31.4 \%$ of respondent's agree to pay MVR 100 and MVR 150 as waste collection fee. While $18.6 \%$ of people agreed to pay MVR 200 as waste collection fee, only $6.9 \%$ of people agreed to pay MVR 250 and only $3.9 \%$ of people agreed to pay MVR 350 as waste collection fee.

Table 2: Association between respondent's satisfaction level and their willingness to pay.

\begin{tabular}{|c|c|c|c|c|}
\hline & & & $\begin{array}{c}\text { Willingness to } \\
\text { pay }\end{array}$ & $\begin{array}{c}\text { Total } \\
\text { satisfaction } \\
\text { level }\end{array}$ \\
\hline \multirow{6}{*}{ Spearman's rho } & \multirow{3}{*}{ Willingness to pay } & $\begin{array}{l}\text { Correlation } \\
\text { Coefficient }\end{array}$ & 1.000 & .165 \\
\hline & & Sig. (2-tailed) & & .098 \\
\hline & & $\mathrm{N}$ & 102 & 102 \\
\hline & \multirow{3}{*}{$\begin{array}{c}\text { Total satisfaction } \\
\text { level }\end{array}$} & $\begin{array}{l}\text { Correlation } \\
\text { Coefficient }\end{array}$ & .165 & 1.000 \\
\hline & & Sig. (2-tailed) & .098 & . \\
\hline & & $\mathrm{N}$ & 102 & 102 \\
\hline
\end{tabular}

To determine the relationship between respondent's satisfaction level and their willingness to pay for the waste management Centre, Spearman's rank-order correlation was run. The results showed that Spearman's correlation coefficient is 0.165 , since the significance value is above 0.05 ; there was no association between respondent's satisfaction level and their willingness to pay more for waste collection service.

Table3: Respondents who use plastic bags.

\begin{tabular}{|c|c|c|}
\hline $\begin{array}{c}\text { Respondents } \\
\text { who uses plastic } \\
\text { bags }\end{array}$ & Frequency & Percent \\
\hline yes & 59 & 57.8 \\
\hline no & 43 & 42.2 \\
\hline Total & 102 & 100.0 \\
\hline
\end{tabular}

Table three shows that 57.8 people uses plastic bags, while $42.2 \%$ of people do not use plastic bags.

Table 4: Respondents who think plastic is harmful to the environment.

\begin{tabular}{|c|c|c|c|}
\hline \multicolumn{2}{|c|}{$\begin{array}{c}\text { Respondents who think } \\
\text { plastic are harmful to the } \\
\text { environment. }\end{array}$} & Frequency & Percent \\
\hline \multirow{2}{*}{ Valid } & yes & 81 & 79.4 \\
\cline { 2 - 4 } & no & 21 & 20.6 \\
\cline { 2 - 4 } & Total & 102 & 100.0 \\
\hline
\end{tabular}

Table 4 shows that $79.4 \%$ of people think plastic is harmful, while, $20.6 \%$ of people think plastic is not harmful to the environment. 
Fathmath Shadiya \& Ali Fawaz Shareef; Title: Application of DPSIR Framework to Explore Effectiveness of Solid Waste Management in the Maldives.. Journal of Biomedical Engineering and Medical Imaging, Volume 7, No 1, February (2020), pp 10-17

Table 5: Result of Chi-square test to see if there was any significant association between respondents who think plastic is harmful and their willingness to use recyclable bag

\begin{tabular}{|c|c|c|c|c|c|}
\hline & Value & df & $\begin{array}{l}\text { Asymp. Sig. } \\
\text { (2-sided) }\end{array}$ & $\begin{array}{l}\text { Exact Sig. } \\
\text { (2-sided) }\end{array}$ & $\begin{array}{l}\text { Exact Sig. } \\
\text { (1-sided) }\end{array}$ \\
\hline Pearson Chi-Square & $.606^{a}$ & 1 & .436 & & \\
\hline Continuity Correction $^{b}$ & .280 & 1 & .597 & & \\
\hline Likelihood Ratio & .599 & 1 & .439 & & \\
\hline Fisher's Exact Test & & & & .463 & .296 \\
\hline $\begin{array}{l}\text { Linear-by-Linear } \\
\text { Association }\end{array}$ & .600 & 1 & .439 & & \\
\hline $\mathrm{N}$ of Valid Cases & 102 & & & & \\
\hline
\end{tabular}

The Pearson Chi- Square vale shown in table 6 is 0.6 . This is more than 0.05 , indicating, there is no association between respondents who think plastic is harmful and their willingness to use recyclable shopping bag.

\section{Discussion and Interpretations.}

Household pays MVR 100 to the island council for solid waste collection service. In a bottom up approach such as Community Based Solid Waste Management System, households play an important role in facilitating the running of the system. Household roles such as segregating waste at domestic level is an important components for the sustenance of solid waste management systems as most islands in the Maldives lack the financial resources to hire manpower to sort waste that are brought to the island waste management Centre, therefore households' willingness to pay for waste collection services compensate for the shortcomings of manpower in the waste management Centre.

Community willingness to pay for the waste management system is an indicator to determine the long term sustainability of the system. (Longe, Longe, \& Ukpebor, 2009). Analysis of the results from table 1 shows $62.8 \%$ of people agrees to pay a fee between MVR 100 to 150, while only 10.8 people agreed to pay a fee more than MVR 150. As fee increases, number of people willing to pay for the collection services decreases. Majority of people are willing to pay a fee between MVR 100 to 150.

Results table 2 shows that there was no association between respondent's satisfaction level and their willingness to pay more for waste collection service. Some of the factors mentioned by (Seth, Cobbina, Asare, \& Duwiejuah, 2014) that influence willingness to pay is, income, education, quantity of waste generated, household size, and age. Therefore these factors may influence the respondent's willingness to pay for the waste collection services rather than the community satisfaction around the waste management system

Plastic pollution is one of the leading concerns in the Maldives. The results from table 5 showed that there was no association between people who think plastic is harmful to the environment and their willingness to use recyclable shopping bags. According to Chen \& Chai (2010) a person's attitude towards environment does not indicate their behavior towards the environment. Chen \& Chai (2010) explains a person's attitude towards the environment is rooted in the person's mind and the degree to which the individual associate him or herself to the natural environment which means, a person who has knowledge about environment issues will only change their behavior merely if their primary need for performance, quality, convenience and affordability were met. The argument from (Chen \& Chai, 2010) advises that 
knowledge on environment problems does not necessarily leads to environmentally friendly behavior. Alteration in behavior is a more complex issues related to the person's own self-identity. That means a person will only adopt environmentally friendly behavior only if the person identifies him /her as a part of the environment and recognize that he/she has a role to play in maintaining the wellbeing of the environment. Based on the results, it can be said that as long as the community does not recognize that they are part of the environment and they have a role to play to maintain the health of the environment, the drivers of waste generation as indicated by DPSIR framework is not addressed in Community Based Solid Waste Management System, implemented in the Maldives, therefore health of threatened coastal habitats from plastic pollution will not be improved even though there is a good governing waste management system in the islands. Unless drivers of waste generation such as consumption behavior are addressed through Community Based Solid Waste Management System, issues such as plastic pollution cannot be solved in the Maldives.

\section{Conclusion.}

With the introduction of plastic, waste management has become a challenge in the Maldives. Nonbiodegradable synthetic materials such as plastic have become one of the leading causes of marine and coastal pollution in the Maldives, as a result, the government of Maldives introduced Community Based Solid Waste Management Systems across Maldivian islands to solve the issues related to waste management at island level. Analysis of data showed, even though most people in the community were satisfied with the new system , there was no association between community satisfaction level and their willingness to pay more for the sustenance of the new system. In addition, even though community was aware about plastic pollution, there was no association between community perception about plastic pollution and their willingness to adopt green consumer behaviors. Individual's attitude towards environment does not indicate their behavior towards the environment because an individual's attitude towards the environment is rooted in the person's mind and the degree to which the individual associate him or herself to the natural environment. Information about environment problems does not necessarily leads to environmentally friendly behavior. Alteration in behavior is a more complex issues related to the person's own self-identity. As a result, a person will only adopt environmentally friendly behavior if the person identifies him/her as an important part of the environment and recognizes that he/she has an important role to play in maintaining the wellbeing of the environment.

\section{REFERENCE}

[1] Carr, R.E., Wingard, M. P., Yorty, C.S., Thompson,C. M., Jensen, K.N.,\& Roberson, J. (2007). Applying DPSIR to sustainable development. International journal of sustainable development \& world ecology, 14,543555.

[2] Chen, T., \& Chai, L. (2010). Attitude towards the environment and green products: consumer's perspective. Management science and engineering, 4,(2), 27-39.

[3] Fry, I. (2005), Small Island Developing States: Becalmed in a Sea of Soft Law. Review of European Community \& International Environmental Law, 14: 89-99. doi: 10.1111/j.1467-9388.2005.00429.x 
Fathmath Shadiya \& Ali Fawaz Shareef; Title: Application of DPSIR Framework to Explore Effectiveness of Solid Waste Management in the Maldives.. Journal of Biomedical Engineering and Medical Imaging, Volume 7, No 1, February (2020), pp 10-17

[4] Longe, E. O., Longe, O. O., \& Ukpebor, E. F. (2009). People's Perception on Household Solid Waste Management in Ojo Local Government Area, in Nigeria. Iranian Journal of Environmental Health Science \& Engineering, 6(3), 201-208.

[5] Maxim, L., Spangenberg, H. J., \& O'Connor, M. (2009). An analysis of risks for biodiversity under the DPSIR framework. Ecological Economics, 69, 12-23.

[6] Ministry of Tourism. (2015). Assessment of solid waste management practices and its vulnerability to climate risks in Maldives Tourism sector. Retrieved from http://www.tourism.gov.mv/downloads/publicaltions/SolidWaste.pdf

[7] National Bureau of Statistics. (2015). Population and housing census 2014: preliminary results revised. Male', Republic of Maldives: Ministry of Finance and Treasury.

[8] Seth, K., Cobbina, S. J., Asare, W., \& Duwiejuah, A. B. (2014). Household demand and willingness to pay for solid waste management service in Tuobodom in the Techiman-North District, Ghana. American Journal of Environmental Protection, 2(4), 74-78.

[9] Shumais, M. (2014). Conceptualizing a waste cost recovery model for Ari Atoll. . Mal'e: Ministry of Environment and Energy.

[10] Skondras, N. A., \& Karavitis, C. A. (2015). Evaluation and comparison of DPSIR framework and the combined SWOT-DPSIR analysis (CSDA) approach: Towards embracing complexity. Global Nest Journal 17(1), 198-209.

[11] United Nations Development programme. (2012).Ukulhas: an example of excellent waste management practices. Retrieved from:

[12] http://www.mv.undp.org/content/maldives/en/home/ourwork/environmentandenergy/successstories/ Ukulhas-an-example-of-excellent-waste-management-practices.html 